\title{
Iranian Civil Rights Movement and Independence Movement in Kosovo? European Union's Role in the Freedom Movements and State-Building
}

\author{
Rajdeep Singh \\ European Studies, Department of regional studies, University of Tehran, Tehran, Iran. \\ E-mail: rajdeepsm@gmail.com \\ Received: January 17, 2019 \\ Accepted: February 13, $2019 \quad$ Online Published: March 1, 2019 \\ doi:10.5430/elr.v8n1p8 \\ URL: https://doi.org/10.5430/elr.v8n1p8
}

\begin{abstract}
Kosovo celebrated its independence in 2008, and many in the Balkans were eager to see finally peace replacing war into the war-torn region. Iranian civil rights movement also shares some interesting features with the Kosovo case. In this paper, we will show how these similarities are being used in Iranian political system. We will investigate the direct correlates between these two cases as well, especially in the case of Diaspora. In the Kosovo case, however, the path to independence has not been as easy and clear as was hoped for in the beginning. Many countries still refuse to recognize Kosovo as an independent state. Among them are even some European Union members. In this study, we explain the reasons behind the lengthy and difficult process of independence. We also investigate role of identity crisis and its direct link to the independence path. In fact, ethnic Albanians were expecting a reunion with their historical homeland in Albania and this mismatch between expectations and reality made it even harder for them to live inside the not yet well-defined new country, Kosovo. On the other hand, language and religious barriers between ethnic Serbs and Albanians in Kosovo keep alive tensions and hostilities in the region. Furthermore, we investigate the way European Union and Kosovo Diaspora play an important role for the future independent country.
\end{abstract}

Keywords: Iran; Iranian civil rights movement; European Union; Kosovo; Serbia; independence; identity; blurred identity; state-building; Diaspora; language identity

\section{Introduction}

Iranian freedom movements can be traced back to the Mosadeq's movement to nationalize the oil and refinery. Then he tried hard to bring democracy and democratic values in Iran, alongside efforts for the oil sector nationalization. Decades have been passed and still Iranian people are struggling to get a good balance of independence, and cooperation, freedom and religion guidance. Many movements have been influencing the political scene these last couple of years but one of them has had a more durable impact on the Iranian psyche and desire for more freedom and civil liberties. This movement is the civil rights movement, which is represented as the left-wing party and called in Persian as "Jenahe chap". Even the mass protests after 2009 election were to some extent echoed some of the political demands of the left-wing party in Iran (Shargdaily, 2017). The left-wing party is considered to be the forerunner of Iranian civil rights movements after the Iran's Islamic revolution in 1979. In this study, we will compare the Kosovo case, the path to independence of a small country in the Balkan, with the strategies adopted by the Iranian civil rights movement. We compare how Iranian freedom movement has similarities in its core principles to the conditions under state-building process, which Kosovo is a contemporary case in point.

State-building has always been a hot topic, readily yielding itself to interesting debates about identity and culture. Things in the Balkans though have never been so easy and clear to predict. When Bosnia began its final moves towards independent after a bloody internal war in the former Yugoslavia, many thought that it will be the turn for people in Kosovo to reach their long-cooked desire to reach independence.

However, even up to now, Kosovo is struggling to become a fully independent country, recognized by its neighbors and the whole world community. There are many factors that may have been the roots to such a delayed and pains-taking move toward independence that should be investigated in their own cultural and political dimension. There have been many studies that point out to the role of Serbia and its policies toward the wider region which would have been the real cause for Kosovo to reach its independence.

Internal conflicts usually have devastating consequences for the social coherence on the society and Kosovo is not an exception to this. In every small village across the region, one cannot but wonder how much the war was destructive 
and brought a whole range of problems for the ordinary people. Despite this, whenever there is an end to the internal struggle in a region, the importance of identity and its long-term implications should be considered. In this study, we look beyond the region to find out the real sources of the extraordinarily slow steps of the young state Kosovo toward its independence dream. Some of the challenges are social in essence.

Kosovo is a religious country with Muslims, Catholics and Orthodox Christians. Even though it is a secular state, religion plays a role in people's lives and many people are in fact conservative. Centuries of conservatism in traditional communities propagates mistrust and suspicion for more modern values such as women's rights and LGBT rights. This is despite having a communist party, which holds that religious beliefs are incompatible with the social norms, ruling over for decades. This shows that the young society in Kosovo faces different types of challenges that need to be addressed in the due manner as to form a more pro-democratic society there.

Koinova (2013) explores the way and conditions under which conflict-generated Diasporas become independent activists, especially in the case of Kosovo, discussing four major types of the Diaspora political mobilization; she provides further evidence of a strong influence of homeland situation in the overall Diaspora political involvement trend. Tansey (2009) notes though that "Yet Kosovo's political status remains unclear... It is too soon to call this territory of about 11,000 square kilometers and two million people either a securely sovereign state or a full-fledged democracy" (p.153). Even the citizenship is still an open question in Kosovo because of the high tension with Serbia. Krasniqi (2012) argues that " the defining characteristics of the Kosovan citizenship are: (i) adoption of the "new-state" model...(ii) tension between civic and multicultural conceptions of citizenship on the one side, and ethnonational conceptions on the other; (iii) contested nature and overlapping jurisdictions"(p.2). Koinova (2011) investigates the reasons Diaspora entrepreneurs in liberal states pursue the sovereignty goals of their original homelands through channels in the host-states and transnational channels which play an important role in the independence movement. Element of democracy is then an important point of appeal for the future recognition of Kosovo by other countries, in both the EU, and other non-EU nations. Kupchan (2005) claims the independence for Kosovo as the last unfinished business in the Balkans and highlights the importance of having an independent Kosovo for the future lasting peace in the region.

Singh (2018) develops a model for the analysis of the cultural load in the semantics. In fact, we find important cultural notions in Albanian language that shows how the national identity is tied to the national language. Tansey (2008) points out that "Kosovo's experience is reflective of a wider shift among aspiring states, which increasingly refer to their democratic legitimacy as a core element of their right to statehood" (p.2). Abazi (2008) brings an Albanian perspective to the Kosovo situation and states that "Kosovo's independence, while contested in diplomatic practice, opens a perspective for the Balkan countries to begin integration into regional and European schemes... Integration into the Euro-Atlantic institutions is an attractive, albeit difficult, process" (p.5). Singh (2018) illustrates the way Norwegian and Persian prepositions bring notions of semantic inter-play between the inner and outer-world and he develops another model for the role of mirroring effects in language semantics. There are signs that language influence in the Albanian identity before the independence had an important impact on people's sense of national pride. How Albanian look at the world? Singh (2018) illustrates how Albanian language builds up different fine-tuned meanings through verb prefix.

Abazi stresses the importance of the European Union and the role it plays an in the overall attraction of independence option for Kosovars, Turkey though supports the process as a safe way to make possible her own EU membership. Many observers, in Kosovo and the international community, forcefully argue that the Kosovo Serb entity was the product of genocide; this was undeniably the case when Serbian forces massacre 45 civilians, mainly male, at Racak. However, Bardos (2008) asserts that such an independent state will rather destabilizes the region further along the ethnic lines as he states that "The support of the United States and some European Union countries for Kosovo's unilateral declaration of independence has in many ways contributed to a deterioration of the security situation in southeastern Europe...that Kosovo was the last open question left over from the breakup of Yugoslavia-is likely to prove wrong" (p.1).

Radeljić (2014) examines approaches and official discrepancies characterising Western European rhetoric with regard to the Kosovo status question and the way different countries have been reacted to the Kosovo independence since its proclamation in 2008. He points out that Given that European involvement in the Yugoslav space in the early 1990s the Kosovo question seemed rather marginal. Radeljić questions the seriousness and readiness of EU to accept whole-heartedly an independent Kosovo and states that " the fact that European Union representatives did not use the 1995 Dayton Peace Accords to also address the autonomous status of Kosovo was a serious matter of concern amongst Kosovo Albanians, interpreted as European disinterest in addressing their needs" (p.2). European Union has 
been always an important player in the Balkans. From the linguistic point of view, Singh (2018) works on the analysis of the different factors influencing the cultural and religious scene in the Middle-East. The Balkan region is usually characterized by the different religious lines, making the inter-faith role part of the daily life for millions.

Another perspective is the emigration trend, since the Kosovo independence proclamation, many people from Kosovo migrated out to the EU countries. Ivlevs and King (2010) reports that better educated ethnic Albanians and those with higher incomes are more likely to exit and that Ethnic Serbs (the largest minority group) are less likely to emigrate than Kosovo"s ethnic majority. Ivlevs and King (2010) work out a statistical report from the survey carried out in Kosovo and state that " the probability of being a potential mover first increases with income up to the level of 318 EUR per earner, and decreases thereafter...this finding could be an indication of the loss of energetic, talented and entrepreneurial people from Kosovo...suggesting that migration costs are important for the decision to migrate, and, in Kosovo, only the relatively wealthy are able to cover them" (p. 16).

Albania also has been a source of aspirations for kosovars, though its influence has not been fully investigated. In fact, we tried in this study to consider all the factors that may play in the current of independence process for Kosovo as to get a much richer perspective in this issue.

\section{Theoretical framework}

In this study, we used the theoretical framework of the comparative analysis of Hroch (1985), where he compares the national movements in seven European countries and the role of patriotic groups inside the boundaries of the new nations. Therefore, three developmental phases are to be distinguished; phase A (the period of scholarly interest), phase $\mathrm{B}$ (the period of patriotic agitation) and phase $\mathrm{C}$ (the rise of a mass national movement). Knowing the importance of patriotic agitation in the whole process of nation building, phase $\mathrm{B}$ will be the main period of interest in this study; phase B is the period where the foundations of a new nation are formed. Just as Hroch (1985) states " The fundamental yardstick of the completeness of a nation's formation is the development of the class structure of the national community...small nations were fully formed when they displayed a class structure typical of capitalist society and their national movement had taken on a mass character"' p. 26). When working through the class formation, phase B comes to play an important role and that's why it is chosen as the best representative of the class formation in the society. Hroch also suggests the typology of the national movement which is illustrated in the table 1.

Table 1. National movement typology

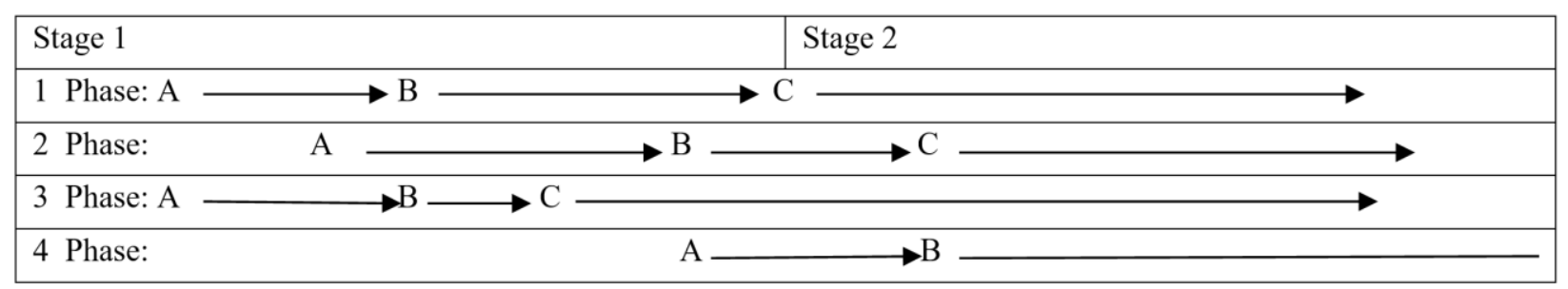

Definitely there is not enough data to be able to place with confidence an exact date for every phase; there approximate dates will be used throughout this study so that the phase B is worked out in order to characterize the patriotic groups and their social background. From Table1 it follows that there are four major types; type 1 (integrated type): national agitation was still present when industrial revolution and bourgeois revolution took place, type 2 (belated): this type is characterized by the late transition to phase $\mathrm{C}$ (national movement transition to mass), type 3 ( insurrectional type): the national movement had already attained a mass character in a feudal society, and type 4(disintegrated type): national agitation first began in a capitalist society.

In order to capture the underlying functions of independent movement in Kosovo, a socio-linguistic element is also investigated under the constructivism theory. It is firmly believed that by combining the socio-linguistic factors and typological characteristics of the national agitation period in Kosovo and Bosnia, we can clarify the reasons why the state formation in Kosovo has been so slow compared to Bosnia; Kosovo is still struggling to be recognized as an independent nation-state, though more than 100 countries have already recognized it as a sovereign state, there are still many countries who have not( ministry of foreign affairs of Kosovo, 2018), in sharp contrast to the republic of Bosnia and Herzegovina which long before was recognized as a sovereign independent state. Comparative analysis will to explain the reasons for such a late state-formation in Kosovo. 


\section{Iranian Civil Rights Movement}

Iran is one of the most important countries in the Middle-East. It is located where everyone tries to get a hand on because of all its rich oil and gas resources and also its strategic position, connecting Western Asia and Europe with the Eastern and Southern Asia. Having said that, many people in Iran, especially the youth, feel more and more marginalized and not accounted for by political movements (Time, 2015). Some social activists estimate as high as $60 \%$ of Iranian population being unhappy with the current political system. The protests or what called "agitations" in Iranian official media after 2009 elections was a clear case in point. After 2009 elections, it rose up as an important political movement and demanded more civil rights. However, it was not the first time a civil rights movement was becoming a force in the Iranian political scenery, being able to influence the internal politics. The left-wing party or jenahe chap in Persian was an important precursor. What we found interesting was the interaction between the left-wing party and outside world since there are similarities in essence between Iranian case and independence movement cases. We will analyze the situation in Kosovo, as an important contemporary independence movement. But before that, we will look at the Iranian case. Figure1 illustrates the international interaction of Iranian left-wing party as the most important contemporary civil rights movement in Iran.

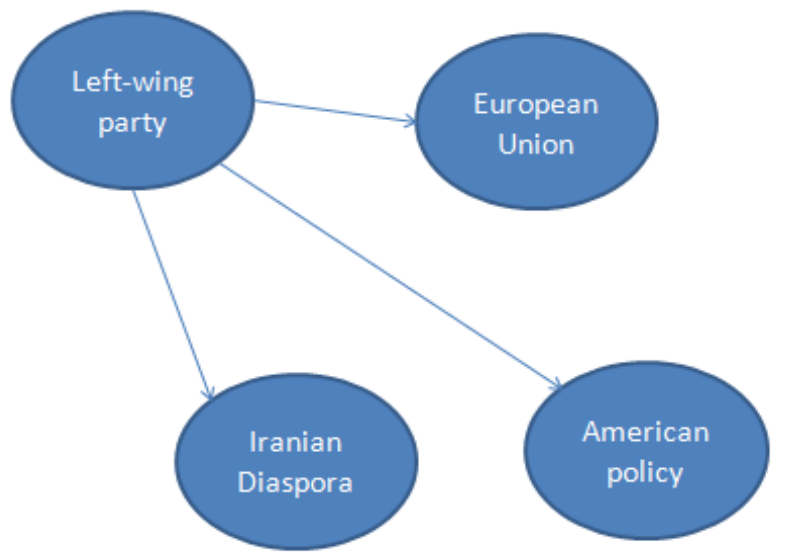

Figure 1. Iranian left-wing party and its international relations

As it is shown, Jenahe Chap, the left-wing, is primarily concerned with relations with western democracies as to build a similar model in the country. Between all the foreign players, the USA and its political weight have always been highlighted and even exaggerated for mere political gains by the Iranian left wing or "jenahe chap". In fact, many in the left-wing party want a better and closer relation with the European Union due to its more direct influence on the Iranian political scene. EU is regarded as a rather neutral player in Iran and it is even amongst the most welcomed whenever Iran finds itself under American sanctions. However, there is a mismatch between Iranian aspirations and the left-wing party leadership concerning Europe. In independence movement cases in Europe, EU has exerted great influence and has been an active supporter of more civil rights in such cases and even beyond across the globe. In Iranian case, however, USA has been regarded as the greater power and a better role model. One of the reasons is that European Union is considered as a trans-national unity and this is a foreign term in Iranian political circle. In fact, many disregard EU as they see it somewhat "less than a united entity". This has had important consequences in Iranian political scene. Many conservative supporters have been happy to see the USA as the only symbolic icon of freedom in Iran and they try active to demote EU as an empty shell without any real political weight to be considered. This has caused many problems for the Left-wing party in Iran as it is often associated with the American policies in the Middle-East. Despite this, the civil rights movement in Iran has recently begun investigating the possibility of more engaged relations with the EU. In the following, we will look at the Kosovo case and how EU has been important in its push to become independent.

\section{Kosovo: the Belated Type in Conditions of Political Autonomy}

After the fall of Ottoman Empire, the principality of Serbia was formed and later in 1882 King Milan I proclaimed the Kingdom of Serbia. The fact that Serbians and Greeks succeeded in creating their own nation-states after centuries of occupation and rule by ottoman had important consequences on other parts of Balkan. While, Albanian people were still ruled under the Ottoman Empire, they feared to be dislocated from their lands and even being 
partitioned among Montenegro, Serbia, Bulgaria and Greece.

Albanians felt that Ottoman Empire was not powerful as before to protect them and newly then formed autonomous neighboring states were a real threat to any plan for their future. One of the most important points to make is that Albanian majority territory which was named as Kosovo Vilayet was so vulnerable to foreign forces, being an enclave. Also, the fact that the majority were Albanian speakers made it even more urgent to finally use the opportunity and to gain independence from the Ottoman Empire. Part of the Kosovo Vilajet in fact succeeded to gain independence in 1912 but the rest remained under the Serbian control. This made things even harder for the then Albanian majority Kosovo under the Serbian control. In order to analyze how and why the Kosovo independent movement was not successful to declare the independence, we need to look back at an important event for the whole Albanian national identity which was the formation of league of Prizren.

\subsection{Besëlidhja e Prizrenit- league of Prizren}

The League of Prizren (Albanian: Besëlidhja e Prizrenit), officially the League for the Defense of the Rights of the Albanian Nation (Albanian: Lidhja për mbrojtjen e të drejtave te kombit Shqiptar), was an Albanian political organization officially founded on June 10, 1878 in the old town of Prizren, in the Kosova Vilayet of the Ottoman Empire. League of Prizren was established at the meeting of 47 ottoman Beys. Table2 illustrates the social composition of the league of Prizren. Clearly the overwhelming majority was with the military officers and the next one was the class of the noblemen and there was only one catholic representative.

Table 2. Social composition of league of Prizren

\begin{tabular}{|l|l|l|}
\hline Categories & Patriots & Percentage \\
\hline Military personal & 34 & $72 \%$ \\
\hline Noblemen, officials & 12 & $25 \%$ \\
\hline Catholic representative & 1 & $3 \%$ \\
\hline
\end{tabular}

League of prizren was formed with the desire of an albanian independent state. We see that high-ranked military officials were involved in this common goal and the sense of identity was present among the participants of the league. In fact, albanian identity much showed up itself as the albanian language was a demarcating line between albanians and others. Here, the religion and language play an important role; in order to see the relation between religion and language, we need to look back at the ottoman empire. In ottoman empire, the concept of ummat, muslim nation, was present in all aspects of life- muslims were considered to be part of one over-encompassing muslim identity.

On the other hand, the concept of millet, nation, was given to people of other faiths. This tension between muslims, and non-muslims was well present before the balkan countries finally celebrated their independence from the yoke of Ottoman Empire. However, albanian speaking population were overwhelmingly muslim, there they were regarded as Ottoman agents and supporters in the balkan region. Despite this, the albanian language was an important factor in the albanian identity and the aspect of religion was rather dull in front of the language identity. That's why participants in the league of Prizren in their first 6 articles of resolutions of the prizren commitee for national defence confirmed their albanian identity many times, just as in article 4 which says "In accordance with our noble religious law (sheriat), we will protect the lives, property and honour of our loyal non-Muslim compatriots as our own, but yet we will act against rebels and punished them according to circumstance and venue.". Though there are still some remnants of the religious beliefs, we see that there is a clear acceptance of non-Muslim Albanians as the compatriots without any distinction.

Article 4 also shows the tension between religion and identity, a problem common to many Muslim communities. The league of Prizren and foundation of republic of Albania clearly show that the sense of Albanian identity existed in the society and many were ready to use force to defend their territory. However, the very independence of Albania made the final push for Kosovo independence much harder.

\section{Dual identity: Albania and Kosovo Dilemma}

When albania gained indepence in 1912, albanians in kosovo felt being left behind and the whole idea of formation of league of prizren seemed non-relevant. In fact, based on the league of prizren, kosovo was part of greater albania and now there was a tension between joining albania and forming repulic of kosovo. The hesitance and uncertainty 
made it much harder for kosovo than other balkan states to gain independence. In fact, many in Kosovo felt and considered themselves primarily Albanians and only secondarily as Kosovars. On the other hand, the serbian government was suspicious of any autonomous status that would amount to forming the greater albnania.

Compared to bosniaks, kosovars were albanian speakers and they had already formed the albanian identity, this makes the Kosovo situation unique and apart from other state-building cases. Even in the league of Prizren, the main goal was the independence of a united great Albania, making the Kosovar identity as nebulous and somewhat left in the dark and background.

This sense of Albanian identity is an important factor in the whole process of indepence for Kosovo, noone can deny the psychological and aspirational goal of unity of the same people in the great Albania, making the need to live an independent Kosovo as less desirable. The identity tensions inside Kosovo is not restricted to Serbs and Albanians, but also involves pro-Albania and pro-Kosovo, this shows how the complex ethnic and identity picture of Kosovo perplexes the whole region. Figure2 illustrates the way the dual identity weakens the order and political arrangement in Kosovo.

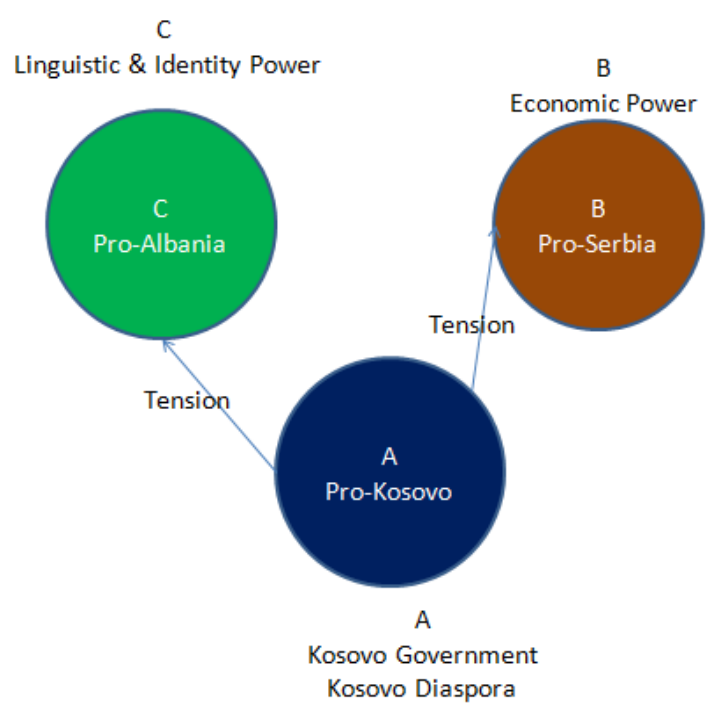

Figure 2. Complex ethnic, economic and identity situation in Kosovo

As it is illustrated in Figure2, the situation is far from simple. We see here how the three blocks compete with one another to win over the future of Kosovo and form the region based on their own identity and economic benefits. Bloch pro-Albania stands for a great Albania "dream homeland" while the pro-Kosovo block does not see a future in reunification and is building its own identity in the process. The diaspora here plays an important role in favor of the block pro-Kosovo which may finally make the path ready for a complete independence. Pro-Serbia block is still the powerful economic block with its natural link to the repulic of Serbia.

\section{Kosovar Diaspora- Influencial Factor}

Homeland Kosovo and its independence is most valuable for the big Kosovar diaspora in different regions of Europe and USA. There are cases of big Kosovar mobilization in the UK and Germany in favor of an independent Kosovo and the identity of Albanian is rather backgrounded. Koinova (2013) argues that "dynamics in the original homeland drive the overall trend toward radicalism or moderation of the Diaspora mobilization in a host-land: high levels of violence are more likely to be associated with radicalism and low levels with moderation... Nevertheless, how Diaspora mobilization takes place is the result of conjuncture of the level of violence with another variable, the linkages of the main secessionist elites to the Diaspora, which can be strong or weak" (p.434). In fact, just as tensions can move from the region to the other countries, the Diaspora can influence the situation as well. Here, what we see is a direct and mutual interaction between Diaspora and homeland. Figure3 illustrates the Diaspora's role in the independence movement in Kosovo. 

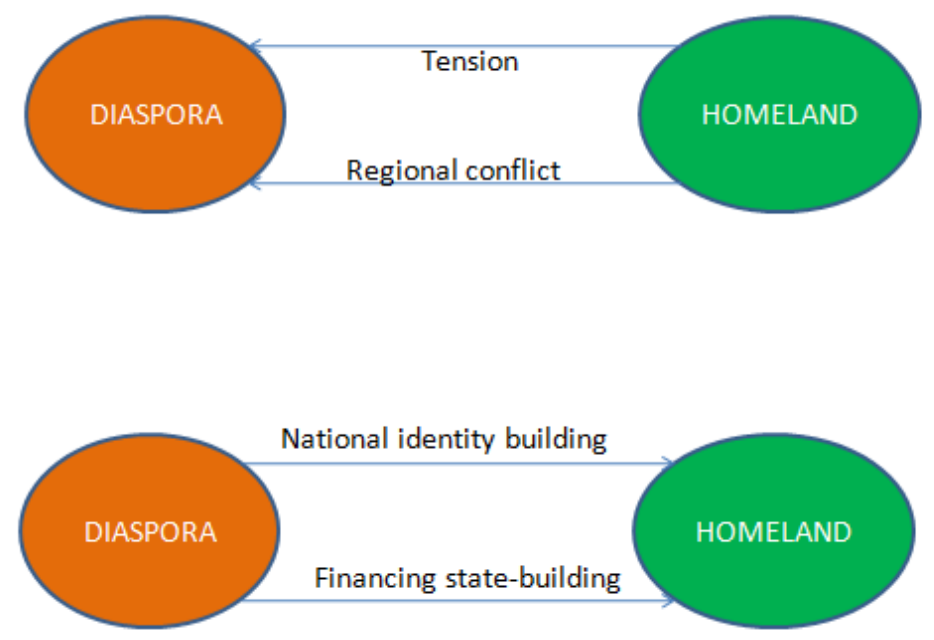

Figure 3. Interaction between homeland and Diaspora

As it is illustrated in Figure3, the role of Diaspora in funding the independence movement in Kosovo is of paramount importance, considering the weak financial situation of Kosovo. Hadri (2018) states that "Data from Kosovo's Central Bank shows that in 2017 was a peak year regarding remittances sent to Kosovo, compared with earlier years. According to the data, 759 million Euros were sent by the Diaspora to Kosovo in 2017. Since 2011, remittances have continuously risen". The financial assistance by the Diaspora plays a major role in the overall sentiment of belongingness and identity inside Prishtina, the city which had the most to lose from an ethnic war, arguably the most of any city in the former Yugoslavia. To many of its residents, this was abundantly clear in 1996 as a nationalist fervour had engulfed the region once again. Four attacks on Serbian security personnel were carried out almost simultaneously in several parts of Kosovo, the first since the beginning of Balkan which split the country along ethnic lines. In fact, without the foreign remittances, the situation will be dire in Kosovo.

Dependency on remittances in Kosovo remains substantial - with 25 per cent of households reporting reliance on remittances, a figure that is even higher among households in rural areas and those headed by women, making the remittance the top priority in the household in Kosovo. The dependence on remittances as a paramount livelihood strategy is clear from the fact that they represent the second largest source of income for remittance-receiving households (UNDP, 2018). Haxhikadrija reports that "Rural households with a migrant family member are more likely than those without a migrant to own a car or a truck $(56 \%$ v. $37.3 \%)$ a refrigerator $(72.3 \%$ v. $60 \%)$ or an electric or gas stove $(63.7 \%$ v. $48.1 \%)$; by contrast, differences are not frequently significant in urban areas" (p.7). Thus, the driving force of the Diaspora, especially in rural areas is of such an importance that the independence movement cannot be considered mature without its contribution. With the direct investment and the money coming back home by the working Kosovo Diaspora in the wealthy western European countries the situation for the newly established Kosovo government may become viable economically; there has been some popular rural dissatisfaction with government policies and the new investment seems to have been a key element to ease the internal tensions in Kosovo.

Beyond this, the cultural ties that the newly formed Kosovo Diaspora has made with different types of organizations, from political organizations to non-governmental organizations, in countries such as UK and Germany may help further enhancing the role of a new pro-Western Kosovo in the future of the Balkans. The public awareness of Kosovo situation made the Western media plays a significant role in representing a more religiously neutral state for Kosovo. In fact, some of the main concerns in Western countries, including the United States of America, has been the role of Islam in the future Kosovo state and many have doubts about the neutrality and secularity of state in Kosovo. However, the Diaspora has shown a very different picture by supporting Western values and getting involved directly into the political scene by the help of different lobby groups. A good example is the WFD, which is a UK based public body dedicated to support democracy around the world. In 2016, Westminster Foundation for Democracy (WFD), in partnership with the British Embassy in Pristina, launched the Transforming Political Governance in Kosovo (TPGK) program that have had important implications in the way the government runs the country by supporting reforms of the political party system in line with European standards; political parties in 
Kosovo are weak and this impedes greater social mobilization for civil rights while secular values are less entrenched and social coherence is lacking in the newly formed state.

\section{Kosovo LGBT Community and Women's Rights}

Kosovo Foundation for Open Society also plays a significant role in bringing Kosovo closer in lines with the European and democratic values, supporting directly different public debates over the women's rights movement and LGBT activists in the country. In views of challenges facing women, a majority of Kosovars say women continue to confront obstacles that make it more difficult for them to get ahead than men. Opinions about the obstacles facing women are divided along gender lines, but the partisan gap is wider than the gender gap.

When it comes to LGBT community, activists face harsh resistance from the public media and they ask for the public to stand up for and with them in demanding inclusive references to their needs. In fact, In Kosovo, the lesbian, gay, bisexual, transgender and intersex (LGBTI) community continues to be a marginalized group and even though it is participating in different public scenes for the support of democratic rights, it is still an invisible group, so little known of this community in the public arena. Prejudice exists in almost all spheres, be public or private. Problems with employments and social ostracism are a real thing for LGBTI persons that force them in many cases to hide their identity. There have been many reports about homophobic incidents in recent years, ushering a new era of fear and prejudice for this weak social group. Even acts of violence and hate attacks in the form of ill remarks again the LGBT persons in public media have been witnessed. In many cases, fear prevented the mere report of such incidence to the police. However, there is no uniform LGBT experience. In the social context, and beyond the media, some people have embraced the LGBTI identity and even support such marginalized persons in the society while others do not have any willingness to be categorized as such or labeled based on the gender. Some faced violence as the only response to their declared identity, while others received pockets of acceptance here and there. Some left Kosovo because of the harsh situation they needed to face in the newly formed state in the Balkans.

Although the presence of feminists and LGBT activists in the public media has been increased in recent years, still it is far from the European standard. These gender related issues show that the society in Kosovo needs more public awareness campaigns and it is where WFD plays an important role. Furthermore, the religious minority groups such as Christian community need more direct support as to find a more representative presence in the Kosovo parliament; Partia Shqiptare Demokristiane e Kosovës, PSHDK, which stands for Albanian Christian Democratic Party of Kosovo, is an important party that is receiving more attention due to the Diaspora and it stands for Christian democratic ideals. PSHHDK has faced some political obstacles in its campaigns and different NGOs in the Western countries have just began demanding more liberties for political parties of minorities.

\section{European Union's Role and Blurred Identity}

European Union has been an inspiration source for many eastern European countries, former communist states, after the fall of Communism; many of them do not see their future out of the common EU and this is a trend that does not seem to stop any time soon. In fact, even after the issue of Brexit, UK leaving EU, countries such as Serbia and Montenegro actively seek further integration; this is despite their strong links with Russia. This is apparent in the way Serbian government seeks joining the EU while maintaining strong ties with Russia. However, EU can play a much more involved role in the Kosovo issue especially as the country is geopolitically located in a very sensitive place in the very heart of the Balkans.

European values are highly appreciated among the youth in both Serbia and Kosovo and they are usually equated with the progress and modernity, showing the big potential the EU has in easing the tensions and making the ground ready for a genuine negotiation between the two states. In fact, the more neutral role EU played in the Kosovo conflict, compared to the NATO and USA, makes it a more acceptable decisive body for the final recognition of an independent Kosovo by the Serbian state.

Kosovo faces even more complex situation when it comes to the aspirations of joining European Union because of its already blurred identity, ranging from Kosovar-Albanians to ethnic Serbs. European Union however plays an important role since it is what both Serbia and Kosovo aspire to join; thus it can enhance the cooperation between the two hostile nations through setting common goals and framework. Furthermore, there is a good perception of European Union in Kosovo and this is a consensus in further integration with EU. Good perception of the EU reached 60\% and 57\% of preferences in 2010 and 2015, respectively (UBO consulting survey), which is illustrated in figure4; this is an important argument for further integration as they see EU as an organization representing the most developed western countries and an entity avoiding conflicts between EU members and promoting peace and good relations among neighboring countries, which was conducted by RIDEA in 2016 and is illustrated in figure5 (RIDEA, 
2016); they also see the right and freedom to travel, study, work and live anywhere in the European Union as the most important benefit deriving from an EU integration which is illustrated in figure6 (UBO consulting survey).

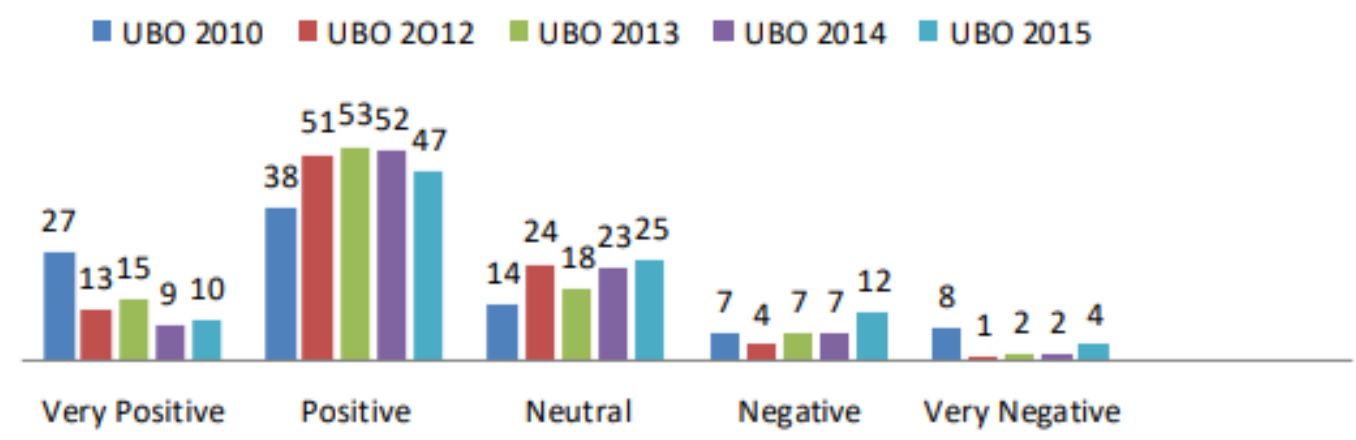

Figure 4. Perception of EU in Kosovo

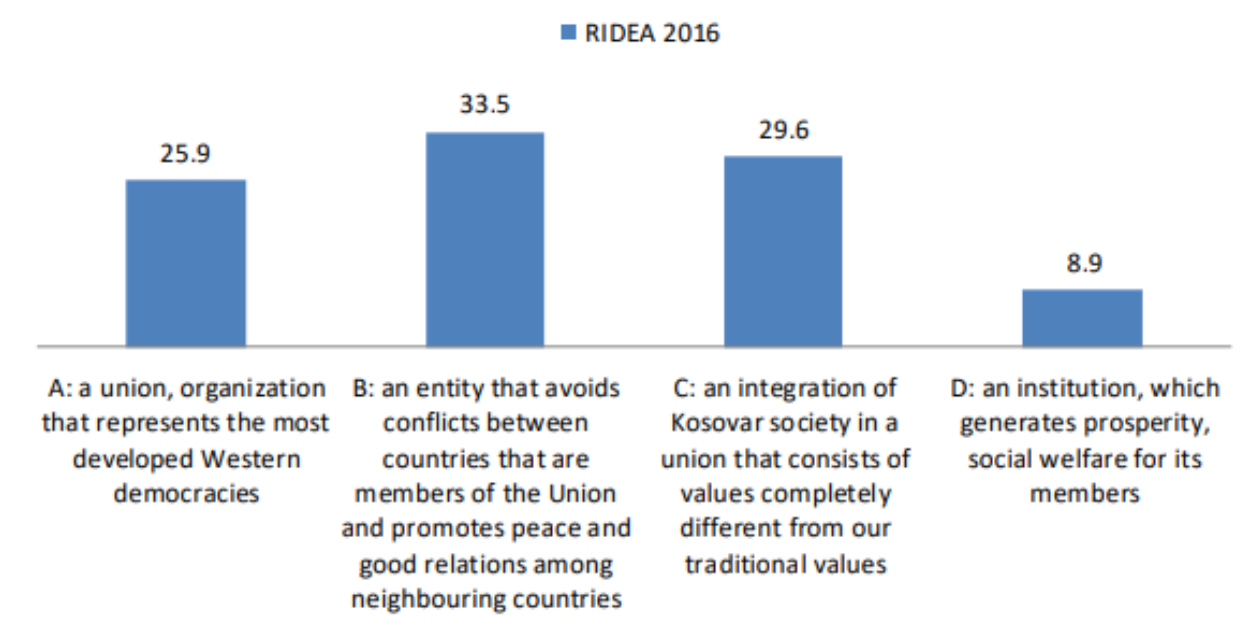

Figure 5. Responses to "What is the EU?"

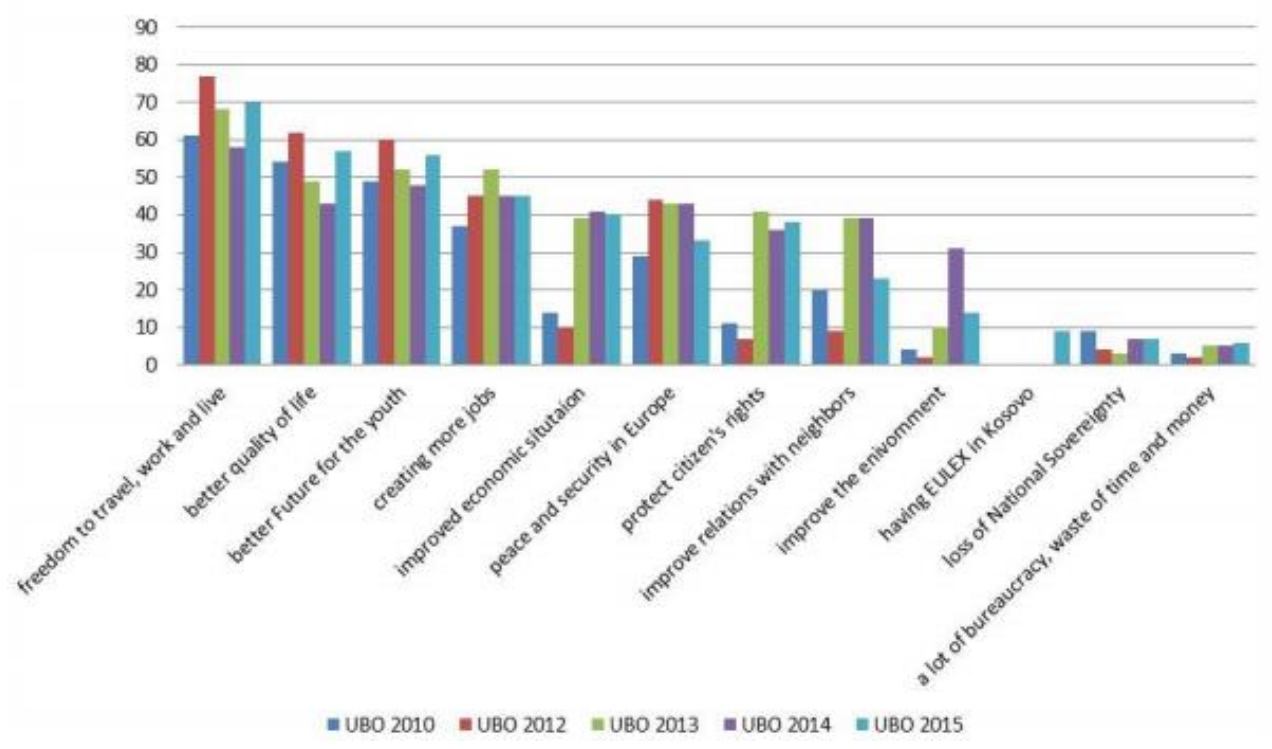

Figure 6. Benefits from entering the EU

European Union will play a major role in the future of Kosovo as it provides that concrete identity for Kosovars 
which they lack due to the blurred identity. In other words, since people in Kosovo see the benefits of joining European union and there is a clear awareness of the benefits among the population, EU seems to orient and direct the efforts toward a clear common identity, European identity, which is significantly neutral to people in Kosovo and Serbia, proving a real alternative for people of blurred identity to feel attached to it.

\section{Conclusion and Discussion}

Kosovo is moving slowly to change the history by becoming an independent state, while its own people consider themselves rather of another allegiance, namely Albania. On the other hand, religious tensions with Serbia and ethnic Serbs inside Kosovo puts pressure on the newly established state to execute its urgent reforms and economic amelioration. On the other hand, the role Diaspora plays is increasingly primordial in establishing the economic prospect of a free, democratic Kosovo.

In this paper, we discussed how the Diaspora-Homeland inter-action and direct financing helps building national identity. European Union is also an important factor in all of this since it is the only strong guarantor of order in region and the main attraction for countries in the fragile Balkans. Inner ethnic tensions between all competing blocks make it even harder to consider an easy outcome for Kosovo, pro-Albanians still dreaming of a reunification with Albania and ethnic Serbs being completely opposed to any system that excludes them from political arena which an independent Kosovo may bring for them.

Despite this, based on our analysis, different powerful blocks in Kosovo are trying to come up with a consensus regarding the best way forward, with the direct involvement of European Union. All of the parties involved try to cooperate so that a better economic and political future may begin emerging for the people in Kosovo. We analyzed the situation culturally and linguistically and shed in light the deep phenomenon of the blurred identity which plays a significant role in the future of Kosovo since it will determine the final form of the new state; the identity issue makes the future of Kosovo as an independent state for ethnic Albanians though more challenging. Kosovo as the birthplace of the Albanian state now faces the harsh and never experienced before situation to form a new neutral Kosovo state while ethnic Albanians for centuries dreamed of forming an independent Albanian state. In the light of these facts, it seems Kosovo needs more international involvement in order to present a more acceptable middle way path to its people and the only international organization that can play this intermediate role is European Union with its clear attraction and popularity among the youth in both Kosovo and Serbia.

We also saw how national movements for improvement of human rights, as it is the case in Iran, are similar to independent movements, like the Kosovo case. In both cases, the Diaspora has an important role to play, influencing directly the way future decisions depend on. Furthermore, EU is an important block that can shape and facilitate the progress of Western and universal values including human rights in these countries.

\section{References}

Abazi, E. (2008). Kosovo Independence: An Albanian Perspective, SETA Policy Brief, Accessible online at http://setadc.org/kosovo-independence-analbanian-perspective/policy-papers/1082

Bardos, G. N. (2008). The regional and international implications of Kosovo independence. Mediterranean Quarterly, 19(4), 54-67. https://doi.org/10.1215/10474552-2008-024

Doder, D. (1993). 'Yugoslavia: New War, Old Hatreds', Foreign Policy. https://doi.org/10.2307/1149057

Haxhikadrija, A. (2009). Diaspora as a driving force in the development of Kosovo: myth or reality?. 18.06.2014 http://www.swiss-cooperation.admin.ch/kosovo/en/Home/PublicationsGoogle Scholar

Hadri, L. (2018). Increasing diaspora investments in Kosovo. Retrieved from https://prishtinainsight.com/increasing-diaspora-investments-in-kosovo/

Hroch, M. (1985). Social Preconditions of National Revival in Europe, Cambridge: Cambridge University Press. https://doi.org/10.2307/j.ctv1rmj5z.46

Ivlevs, A., \& King, R. (2010). "Kosovo - winning its independence but losing its people? Recent evidence on emigration intentions and preparedness to emigrate" forthcoming in International Migration. Also available as GEP working paper 2009/17, University of Nottingham.

Koinova, M. (2011c). Why Do Conflict-generated Diasporas Pursue Sovereigntybased Claims through State-based or Transnational Channels. Revised draft of the Paper presented at the Explaining Diaspora Politics workshop, SOAS, London, October 30-31, 2009. https://doi.org/10.1177/1354066113509115

Koinova, M. (2013). Four Types of Diaspora Mobilization: Albanian and Kosovo Independence in the US and UK. 
Foreign Policy Analysis, 9(4), 433-53. https://doi.org/10.1111/j.1743-8594.2012.00194.x

Krasniqi, G. (2012). Overlapping Jurisdictions, Disputed Territory, Unsettled State: The Perplexing Case of Citizenship in Kosovo. Citizenship Studies, 16(3-4), 353-66. https://doi.org/10.1080/13621025.2012.683214

Kupchan, C., A. (2005). Independence for Kosovo: Yielding to Balkan Reality. Foreign Affairs, 84, 14-20. https://doi.org/10.2307/20031773

Lampe, J. (1996). Yugoslavia as History. Twice there was a Country, Cambridge: Cambridge University Press. https://doi.org/10.1086/ahr/103.4.1281

Ministry of foreign affairs of the republic of Kosovo. (2018). Retrieved from: http://www.mfa-ks.net/subdomain/oldwebsite/?page $=1,224$

Radeljić, B. (2014). Official Discrepancies: Kosovo Independence and Western European Rhetoric. Perspectives on European Politics and Society, 15(4), 431-444. https://doi.org/10.1080/15705854.2014.893706

Singh, R. (2018). Derivational Grammar Model and Basket Verb: A Novel Approach to the Inflectional Phrase in the Generative Grammar and Cognitive Processing. English Linguistics Research, 7(2). https://doi.org/10.5430/elr.v7n2p9

Singh, R. (2018). A Cognitive Approach to the Semantics in the Sacred Context: Semantic and Symbolic Function of Sacred Words. English Linguistics Research, 7(3). https://doi.org/10.5430/elr.v7n3p1

Singh, R. (2018). Norwegian and Persian spatial prepositions: a novel comparative and syntactic approach to the spatial prepositions. KAAV international journal of English, literature, and linguistics, vol.5/ page no.1-8. Retrieved from: http://www.kaavpublications.org/journals/journal-5/article/article-1788.pdf

Singh, R. (2018). Areas of errors and difficulty for Persian learners of Spanish caused by the sound system differences between Persian and Spanish: A phonetic approach to inter-lingual system. KAAV international journal of English, literature, and linguistics, vol.5/ page no.1-8. Retrieved from: http://www.kaavpublications.org/journals/journal-5/abstract/abstract-1996.pdf

Singh, R. (2018). Mirroring Effects and the Water Code: A Cognitive-Semantic Approach to Natural Morphology in the Religious-Cultural Context. Journal of Literature, Languages and Linguistics, vol.46/page no.37-41. Retrieved from: https://www.researchgate.net/profile/Rajdeep_Singh22/publication/329922433_Mirroring_Effects_and_the_Wat er_Code_A_Cognitive-Semantic_Approach_to_Natural_Morphology_in_the_Religious-Cultural_Context/links/ 5c23ac09458515a4c7fad9aa/Mirroring-Effects-and-the-Water-Code-A-Cognitive-Semantic-Approach-to-Natura 1-Morphology-in-the-Religious-Cultural-Context.pdf

Singh, R. (2018). Russian and Negative Prefixing: A Cognitive-Semantic Approach to the Negative Adjective Prefixing in Russian, Spanish, Persian, and English. English Linguistics Research, 7(4). https://doi.org/10.5430/elr.v7n4p7

Singh, R. (2018). Auxiliary Verbs in Serbo-Croatian, French, Persian, Spanish and English: A Cognitive-Semantic Approach to the Auxiliary Verb Usage and Passive Voice. English Linguistics Research, 7(3). https://doi.org/10.5430/elr.v7n3p34

Singh, R. (2018). Language change and directionality: A novel model for language change in Persian and Iranian languages from the sociolinguistic perspective. KAAV International journal of English, Literature, and linguistics, 5, 1-8. Retrieved from: http://www.kaavpublications.org/journals/journal-5/article/article-1876.pdf

Singh, R. (2018). Error Analysis of Persian Learners of Hausa Language: Cognitive Approach to Errors. Journal of Literature, Languages and Linguistics, 45, 10-15. Retrieved from: https://www.researchgate.net/profile/Rajdeep_Singh22/publication/329922323_Error_Analysis_of_Persian_Lea rners_of_Hausa_Language_Cognitive_Approach_to_Errors/links/5c23aac9458515a4c7fad97b/Error-Analysis-o f-Persian-Learners-of-Hausa-Language-Cognitive-Approach-to-Errors.pdf

Singh, R. (2018). Albanian World-View: Co-Locativity as the Schematic Meaning of Albanian Verbal Prefix Bashke-. English Linguistics Research, 7(4). https://doi.org/10.5430/elr.v7n4p28

Singh, R. (2018). Christian And Sikh Communities in Iran And Role of Language Identity: A Comparative Approach to the Social-Linguistic Aspects of the Christianity And Sikhism in the Middle East. Sikh Research Journal, 3(1). Retrieved

from: http://www.sikhfoundation.org/wp-content/uploads/2018/sikh-research-journal/Rajdeep_Singh-Sikh_Christian_ 
community_in_iran_and_the_language_identity_bahai.pdf

Tansey, O, (2008). Does Democracy Need Sovereignty? Review of International Studies, 37(4), 1515-1536. https://doi.org/10.1017/s0260210510001087

Tansey, O. (2009). Independence and tutelage. Journal of Democracy, 20(2), 153-166. https://doi.org/10.1353/jod.0.0068

UNDP, United Nation Development Plan. (2018). How to Become a Driving Force: Kosovo Diaspora. Retrieved from

http://www.ks.undp.org/content/kosovo/en/home/ourwork/povertyreduction/successstories/how-to-become-a-dri ving-force--kosovo-diaspora-.html 